\title{
Tajemství Janáčkova klavírního cyklu Jarní píseň (Co ukrývala skladatelova korespondence)
}

\section{The Secret of the Janáček's Piano Cycle Spring Song (What Was Hidden in the Composer's Correspondence)}

Jiří Zahrádka / jiri.zahradka@seznam.cz

Ústav hudební vědy FF MU; Oddělení dějin hudby MZM, Brno, CZ

\begin{abstract}
In 1937, in Pazdírek's Music Dictionary's entry dedicated to Leoš Janáček, the lost piano cycle Spring Song (1912) is mentioned for the first time. The author of the article was Vladimír Helfert. From this moment on, this composition became part of Janáček's listings until John Tyrrell expressed doubts about its existence in the Catalogue of Janáček's works.

Spring Song is always mentioned in connection with another Janáček's piano cycle - In the Mists. Helfert attributed the Spring Song to Janáček mistakenly on the basis of a review of piano works registered for the competition of the Club of the Friends of Art in 1912, sent by Karel Hoffmeister to Janáček on 25 November 1912. Hoffmeister comments on two compositions, In the Mists and Spring Song. The latter was in fact by Janáček's pupil Vilém Petrželka who submitted anonymously the fourth part - Elegy - of his cycle of Four Pieces for Piano, Op. 3. Janáček, however, sent to Hoffmeister the whole cycle and it is its first piece that bears the title Spring Song. So now we can cross the mysterious lost piano cycle Spring Song out of the list of Janáček's works.
\end{abstract}

\section{Key words}

Leoš Janáček, Club of the Friends of Art in Brno, piano cycle In the Mists 
Snad každé vědecké osobnosti se někdy stalo, že se v jejich jinak přínosném díle objevila více či méně podstatná chybička. To se pochopitelně nevyhnulo v př́ípadě bádání o Leoši Janáčkovi ani Vladimíru Helfertovi, jehož janáčkovský výzkum je jinak nesporně základním pilířem tohoto badatelského okruhu. První chybičku nalezneme v Janáčkově rodokmenu v prvém dílu janáčkovské monografie $V$ poutech tradice. Tu korigovala Dr. Svatava Přibáňová ve studii Nové poznatky $k$ rodokmenu Leoše Janáčka. ${ }^{1}$

Druhá chybička je naprostou marginálií, ale je o to zajímavější, že později stála u zrodu Janáčkovy neexistující skladby.

Klavírní cyklus Jarní píseň se v provizorních soupisech Janáčkových děl z dvacátých let 20. století neobjevuje. Neuvádí jej ani skladatel ve své autobiografii, nezačlenil ji do monografie ani Max Brod. Poprvé se s touto Janáčkovou kompozicí setkáváme až v roce 1937, kde je uvedena v Pazdírkově hudebním slovníku naučném, v hesle Leoš Janáček, jehož součástí je také soupis díla. Zde čteme: Jarni piseň (cyklus 1912, nezachována). ${ }^{2}$ Autorem tohoto hesla není nikdo jiný než Vladimír Helfert. Tak se zrodil tajemný, nedochovaný skladatelův opus, který se dál linul janáčkovskou literaturou i soupisy děl. Píše o něm Bohumír Štědroň v předmluvě cyklu $V$ mlhách $^{3}$ i v soupise Janáčkova díla z roku 1959, ${ }^{4}$ zmiňuje se o něm Theodora Straková, ${ }^{5}$ Jaroslav Vogel $^{6}$ a další. Pochybnosti o Janáčkově autorství tohoto cyklu vyjádřil až John Tyrrell v katalogu Janáčkova díla. ${ }^{7}$

Kde se tedy zrodila souvislost tohoto cyklu s Janáčkem, a proč jej Vladimír Helfert začlenil do katalogu? Na vině je dopis z 25. listopadu 1912, v němž klavírista Karel Hoffmeister zasílá svá hodnocení dvou klavírních skladeb, zaslaných Leošem Janáčkem: „Ze zaslaných dvou klavirnich cyklů rozhodně daleko milejši byly by mi ,Mlhy' než ,Jarni písen̆ atd. Když hledal jsem v poslednějšich osobnost - ne osobu - všimnul jsem si teprve, že je to op. 3 - je to tak málo původni, tak nějaké vlivy se v tom obrážeji, a při tom celý moderni apparát komposični ve zbrani!"8 Je zvláštní, že tento dopis, ve kterém je v souvislosti s Jarni pisní uvedena informace o opusu tři, vedl Helferta k domněnce, že Janáček napsal v roce 1912 klavírní cykly dva - V mlhách a Jarni piseñ.

Nyní se pokusíme tento případ uvést na pravou míru. Jelikož je Jarní piseň vždy uváděna v souvislosti s cyklem $V$ mlhách, musíme svou pozornost zaměřit také na něj. Skladby Jarni písěn i $V$ mlhách mají spojitost se skladatelovou organizační činností v hudebním odboru Klubu přátel umění. Ten měl mimo pořádání koncertů také snahu vydávat noto-

1 P̌̌IBÁŇOVÁ, Svatava. Nové prameny k rodokmenu Leoše Janáčka. In Časopis Moravského muzea v Brně, roč. 65/1984, vědy společenské, s. 129-138.

2 HELFERT, Vladimír. Janáček Leoš. Pazdírki̊v hudebni slovnik naučný. Část osobní (edit. Gracian Černušák, Vladimír Helfert), Brno 1937, s. 475.

3 ŠTĚDROŇ, Bohumír. V mlhách. In Leoš Janáček V mlhách. HMUB, Praha 1949, nepag.

4 ŠTĚDROŇ, Bohumír. Dílo Leoše Janáčka. Abecedni seznam Janáčkových skladeb a úprav. Bibliografie a diskografie. Knižnice Hudebních rozhledů, roč. V., sv. 9, Praha 1959, s. 36.

5 STRAKOVÁ, Theodora - VESELÝ, Vítězslav. Janáčkova skladatelská činnost. In Leoš Janáček Obraz života a dila (red. Jan Racek), Brno, 1948, s. 36.

6 VOGEL, Jaroslav. Leoš Janáček. Život a dílo. Praha: Státní hudební nakladatelství, 1963, s. 196.

7 SIMEONE, Nigel - TYRRELL, John - NĚMCOVÁ, Alena. Janáček's works. Clarendon Press, Oxford 1997, s. 349-350.

8 Dopis je uložen v JA MZM, sign. B 133. 
vý materiál moravských skladatelů a dokonce iniciovat vznik nových děl prostřednictvím soutěží, jejichž vítězům byla skladba vydána tiskem. Prvním vydavatelským počinem bylo v roce 1908 první vydání klavírního výtahu Janáčkovy opery Jeji pastorkyña, o dva roky později, 25. září 1910, se na schůzi hudebního odboru začala diskutovat možnost využitî 1000 korun na tzv. „Moravskou hudební edici“ (pod tímto názvem však nikdy žádné Z vydaných děl nevyšlo). ${ }^{9}$ Janáček na výboru navrhl, aby byli moravští skladatelé vyzváni zadat své novinky Klubu přátel umění k prvnímu provedení a případně k vydání tiskem. Nejlepší ze skladeb by pak posoudili komisaři, které vybral Janáček, a kteří byli v mezinárodním kontextu uznávaní skladatelé a kritici: Josef Bohuslav Foerster, Felix Nowowiejski a William Ritter. ${ }^{10}$ Ještě v témže roce, na schůzi výboru 8. prosince, byl navržen seznam 34 skladatelů, kteří byli vyzváni $\mathrm{k}$ účasti na soutěži a mezi kterými nechyběl ani Leoš Janáček. ${ }^{11}$ Protože do soutěže nedorazilo očekávané množství skladeb, navrhl Janáček 23. června 1911, aby výzva byla uveřejněna v novinách. ${ }^{12}$ Soutěže se nakonec zúčastnilo devět skladatelů, mezi nimiž Janáček nefiguroval, ale nakonec byly pro porotu vybrány pouze tři skladby: klavírní cykly od Jaroslava Svobody a Josefa Nešvery a písně bývalého Janáčkova žáka a funkcionáře hudebního odboru Jana Kunce..$^{13}$ Ač se úsudky tří porotců v mnohém lišily, shodli se na tom, že díla jsou invenčně slabá. Proto se výbor 27. března 1912 rozhodl žádné z nich nevydat tiskem a soutěž vypsat znovu, tentokrát však pouze pro klavírní a pěvecký obor. ${ }^{14}$ Oficiálně se tak stalo až 10., respektive 12. ř́jina 1912. ${ }^{15}$

První soutěžní výzva, stejně jako dojem z poslechu hudby Clauda Debussyho, kterou Janáček slyšel krátce před soutěží na II. symfonickém koncertě pořádaném varhanickou školou (Reflets dans l'eau a Doctor Gradus ad Parnassum z cyklu Dětský koutek), ${ }^{16}$ mohly přispět k jeho rozhodnutí zkomponovat právě klavírní skladbu. Navíc možnost záhy ji vydat tiskem pro něj jistě byla lákavá.

První zmínku o klavírním cyklu s názvem Mlhy máme až z 21. dubna 1912, kdy Janáček zaslal opis víceméně finálního znění do Prahy Dr. Janu Branbergerovi s prosbou, aby na kompozici upozornil v časopise Čas, jako to již dříve učinil v př́ípadě cyklu Po zarostlém chodničku ${ }^{17}$ Tehdy právě Branbergerův kladný referát pomohl Janáčkovi získat nakladatele. Branberger tentokrát posudek nenapsal, ale předal Janáčkův rukopis Jindřichu Pihertovi, který se recenze ujal. Z jeho pochvalného posudku publikovaného 5. prosince 1912 víme, že Janáček zaslal Branbergerovi jediný, tzn. poslední, finalizovaný opis skladby.

9 Zápis z 20. schůze je zaznamenán v deníku hudebního odboru Klubu přátel umění (dále HO KPU) uloženého v JA MZM, sign. D 251/LJ.

10 Tamtéž.

11 Zápis z 24. schůze tamtéž.

12 Zápis z 25. schůze tamtéž.

13 Tamtéź; Anonymus: Oznámení. Moravská orlice, roč. XLIX, č. 275, 2. 12. 1911, s. 10.

14 Zápis z 27. schůze je zaznamenán v deníku HO KLU, viz pozn. 7.

15 Anonymus: Hudební soutěž. Moravská orlice, roč. L, č. 235, 12. 10. 1912, s. 5.

16 Program koncertu z 28. 1. 1912 pořádaného varhanickou školou je uložen v Janáčkově archivu Moravského zemského muzea (dále JA MZM), sign. JP 99.

17 Dopis je uložen v JA MZM, sign. B1442, dopis citován: Korespondence Leoše Janáčka (ed. Jiří Zahrádka a kol.), http://www.musicologica.cz/korespondencejanacek/ (5.2.2016); dále Korespondence LJ. 
O Jarni pisni nepadla ani zmínka. Mezitím výbor hudebního odboru Klubu přátel umění stanovil lhůtu zadání skladeb do soutěže na 1. listopad 1912. ${ }^{18}$ Janáčkovi vrátil recenzent rukopis klavírního cyklu až 5 . listopadu, tedy pět dnů po uzávěrce soutěže, což ale nebyl problém, protože Janáček sám rukopisy do soutěže shromažd’oval. ${ }^{19}$ Jelikož členové původní hodnotící komise se dle Janáčkova mínění př́liš lišili v názorech, bylo rozhodnuto, že členové výboru sami skladbu vyberou, přičemž jednotlivé kusy posoudí ještě klavírista Karel Hoffmeister (v případě skladeb klavírních), muzikolog Dr. Jan Branberger a jeho chot', pěvkyně Doubravka Černochová-Branbergrová (v případě písní). Patrně i proto, že Janáčkovi byl vyčítán zbytečně kritický postoj k písním jeho žáka Jana Kunce v minulé soutěži, sám na novou soutěž upozornil jiného svého žáka, Jaroslava Kvapila. Anonymně zaslaných skladeb se tentokrát sešlo sedm, přihlášených pod hesly. Anonymita byla striktně dodržována, ale odhalení jednotlivých autorů skladeb nebylo tak složité kvůli nepořádnosti Janáčka, který neúspěšným soutěžícím zapomněl poslat skladby zpět a ti jej pak v korespondenci opakovaně upomínali. Jde o skladby: 8 skladeb $k$ soutěži L. A. (5 písní a 3 klavírní skladby) Anny Lacmanové, ${ }^{20}$ Radhošt (písně Černé oči a Jedú chlapci) od Antonína Brotana, ${ }^{21}$ Prosté motivy Milana Balcara, ${ }^{22}$ dále skladby Janáčkových bývalých žáků: Tři skladby pro klavír J. N. Jana Nepomuka Poláška, ${ }^{23}$ Cyklus pisni na slova Antonína Sovy a Adolfa Heyduka Jaroslava Kvapila, ${ }^{24} 4$. číslo cyklu Elegie Viléma Petrželky ${ }^{25}$ a Janáčkovy Mlhy. ${ }^{26}$ Janáček dal nejprve skladby k posouzení recenzentům. Karel Hoffmeister zaslal 25. listopadu Janáčkovi svůj posudek klavírních skladeb, ve kterém vyzdvihl části cyklu Mlhy jako kompozice, které „[...] maji krátkodechý mélos, ale jsou ve své zvláštni rytmice a harmonizaci svérázny a duchaplny. [...] celek působi na mne ve svém improvisatorickém půvabu silou náladovou poesii [...]." ${ }^{27}$ Další recenzovanou skladbou byla Jarni píseñ, kterou, jak víme, Hoffmeister hodnotil jako nepůvodní a nevyzrálou, což podle recenzenta také odpovídalo opusovému číslu tři a navíc šlo o kompozici po technické stránce jen obtížně hratelnou. Celkově tedy Hoffmeister doporučil Janáčkovy Mlhy. Manželé Branbergerovi ze dvou zaslaných písňových cyklů doporučili Cyklus písni na slova Antonína Sovy a Adolfa

18 Viz pozn. č. 15.

19 Dopis Jindřicha Piherta Leoši Janáčkovi z 5. 11. 1912, je uložen v JA MZM, sig. A 442, dopis citován: Korespondence $\mathrm{LJ}$.

20 Jméno dohledáno z autorčiny korespondence se Zdenkou Illnerovou z ?.?. 1912, 24. 2. a 28. 2. 1913 uložené v JA MZM, sign. A 486, A 487, A 488, dopis citován: Korespondence LJ.

21 Jméno dohledáno z autorovy korespondence s Leošem Janáčkem z ?. ?. 1912, 7. 3. 1913 uložené v JA MZM, sign. D 1108, A 4550, dopis citován: Korespondence LJ.

22 Jméno dohledáno z autorova dopisu Leoši Janáčkovi z 29. 10. 1912 uloženého v JA MZM, sign. A 4551, dopis citován: Korespondence LJ.

23 Jméno dohledáno z autorovy korespondence s Leošem Janáčkem z 21. 9. 1913 a Janáčkem zapsaného hesla a autora v obálce z roku 1912. Obé uloženo v JA MZM, sign. A 5488, A 4596, dopis citován: Korespondence LJ.

24 Autor vítězné skladby byl odtajněn.

25 Jméno dohledáno z autorova korespondenčního lístku zaslaného Leoši Janáčkovi 25. 2. 1913 uloženého v JA MZM, sign. A 4589, dopis citován: Korespondence LJ.

26 Zápis z 33 schůze konané 9. 11. 1912 je zaznamenán v deníku HO KPU, viz pozn. č. 9.

27 Viz pozn. č. 8. 
Heyduka. ${ }^{28}$ Jako další recenzent byl nakonec opět přizván J. B. Foerster. Ten doporučil Prosté motivy. ${ }^{29}$ Poté 2. prosince 1912 skladby vyslechli v provedení pedagogů varhanické školy i členové výboru, kteří je rovněž ohodnotili. Mlhy a Jarni piseň tak poprvé zahrála, ač pouze členům výboru, klavíristka Marie Dvořáková. Bodování dopadlo ve prospěch výběru částí z Cyklu pisni Jaroslava Kvapila a Janáčkových $M l h .^{30}$ Jelikož však mohla být vydána pouze jedna ze skladeb, Janáček se vydání vzdal ve prospěch svého oblíbeného studenta.

A Jarni piseň? Tu ve skutečnosti napsal skladatel a Janáčkův žák Vilém Petrželka a je první částí jeho cyklu Čtyři klavirni skladby, op. 3. Petrželka poslal do soutěže pouze čtvrtou část cyklu nazvanou Elegie a označil ji heslem „4. č́slo cyklu Elegie“. Janáček však Hoffmeistrovi omylem poslal k posouzení celý Petrželkův cyklus a ne pouze jeho čtvrtou část. Tak se do Hoffmeisterovy zprávy dostala i zmínka o první části cyklu, která nese název Jarni piseñ.

Dnes si tak můžeme s klidným svědomím ze soupisů Janáčkova díla nadobro vyškrtnout klavírní cyklus Jarní piseň, který do něj vložil v roce 1937 právě Vladimír Helfert. Pravdou však zůstává, že takový drobný omyl je v obrovském Helfertově díle zcela zanedbatelný.

Závěrem bych rád upozornil na to, že výše uvedené souvislosti mezi autory a jejich kompozicemi by se jen těžko podařilo dohledat bez možnosti využití podrobných vyhledávacích funkcí, kterými disponuje detailní online databáze Janáčkovy korespondence, jejíz zpracování je nyní po deseti letech intenzivní práce téměř u konce. ${ }^{31}$

Studie vznikla v rámci projektu Korespondence Leoše Janácka. Finálni etapa edičního zpracováni fondu uloženého v Oddèleni dějin hudby Moravského zemského muzea a dalších institucích. Řešitel Ústav hudebni vědy FF MU, spoluřěsitel Moravské zemské muzeum za finančni podpory Grantové agentury ČR (reg. č́slo P409-12-025) a Nadace Leoše Janáčka.

28 Dopis Jana Branbergera Leoši Janáčkovi z 27. 11. 1912 je uložen v JA MZM, sign. A 4552, dopis citován: Korespondence LJ.

29 Dopis J. B. Foerstera Leoši Janáčkovi z 16. 11. 1912 je uložen v JA MZM, sign. A 4701, dopis citován: Korespondence $\mathrm{LJ}$.

30 Dokumenty k soutěži Klubu přátel umění jsou uloženy v JA MZM, sign. D 244 LJ.

31 Korespondence Leoše Janáčka. Finální etapa edičního zpracování fondu uloženého v Oddělení dějin hudby Moravského zemského muzea a dalších institucích. Řešitel Ústav hudební vědy FF MU, spoluřešitel Moravské zemské muzeum za finanční podpory Grantové agentury ČR (reg. číslo P409-12-025) a Nadace Leoše Janáčka. 


\section{Bibliography}

\section{Sources and literature}

HELFERT, Vladimír. Janáček, Leoš. In Pazdirkưv hudebni slovnik naučný. Část osobní. Brno 1937, s. 475.

KUNDERA, Ludvík. Janáček a Klub prátel uměni. Olomouc: Nakl. Velehrad, 1948.

KUNDERA, Ludvík. Janáčkova tvorba klavírní. In Musikologie, 3 - 1955, s. 306-329.

PROCHÁZKOVÁ, Jarmila. V mlhách. Brno: Moravské zemské muzeum, 1997.

SIMEONE, Nigel - TYRRELL, John - NĚMCOVÁ, Alena. Janáček's Works. Oxford: Clarendon Press, 1997.

TYRRELL, John. Janáček. Years of a life. Volume I. London: Faber and Faber, 2006.

WINGFIELD, Paul. Janáček's V mlhách: towards a new chronology. In Časopis moravského muzea, roč. XXII, 1987, s. 189-204.

Korespondence Leoše Janácka [online]. (ed. Jiří Zahrádka a kol.). Dostupné z: 〈http://www.musicologica.cz/korespondencejanacek/>. 


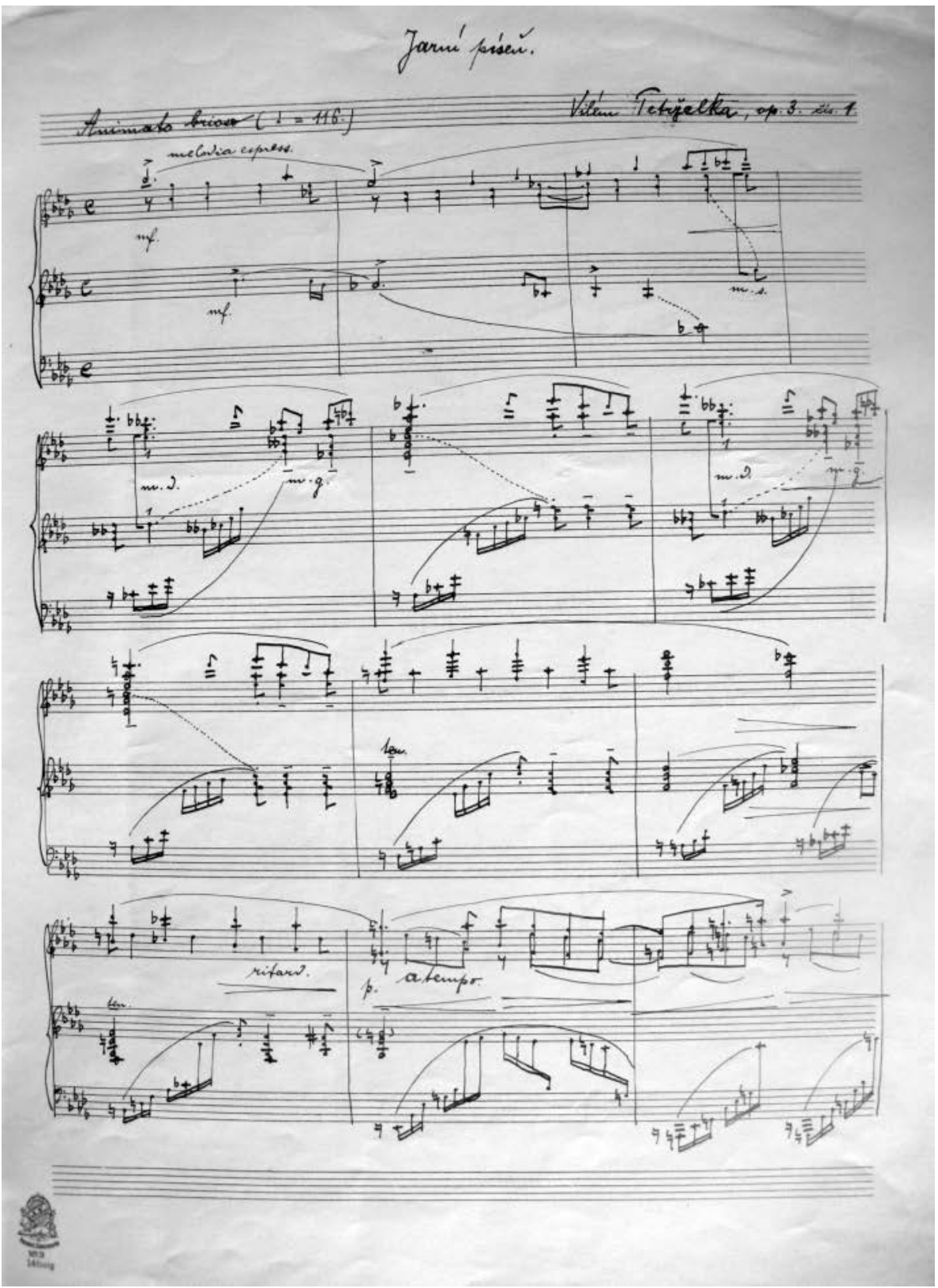

Obr. 1. První strana Petrželkova autografu Jarní píseň. Uloženo v ODH MZM, sine sign. 
Tajemství Janáčkova klavírního cyklu Jarní píseň (Co ukrývala skladatelova korespondence)

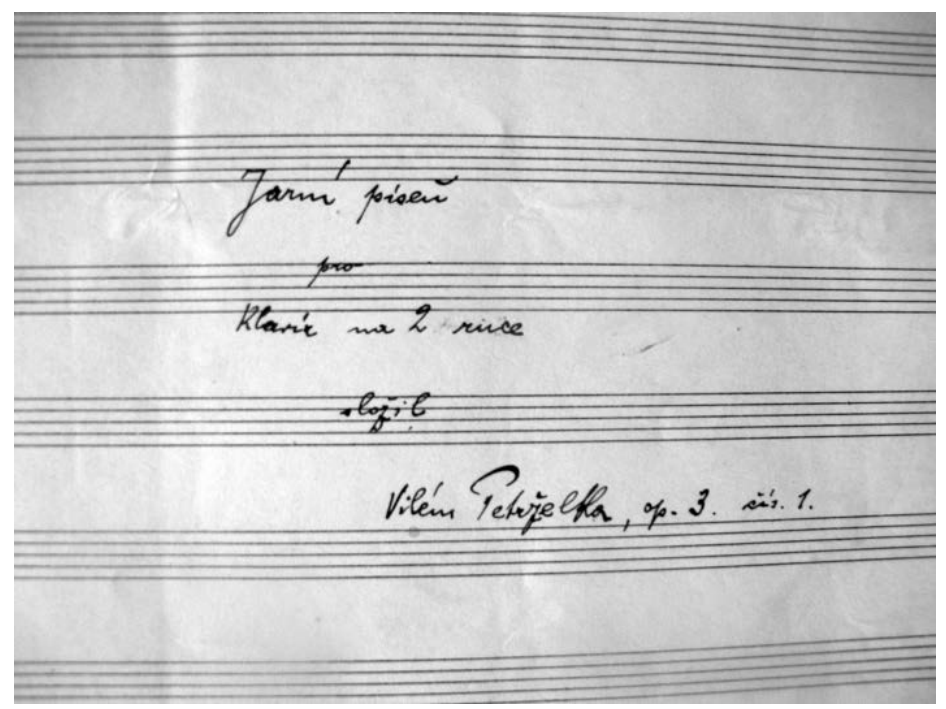

Obr. 2. Titulní list Jarní písně. Uloženo v ODH MZM. 


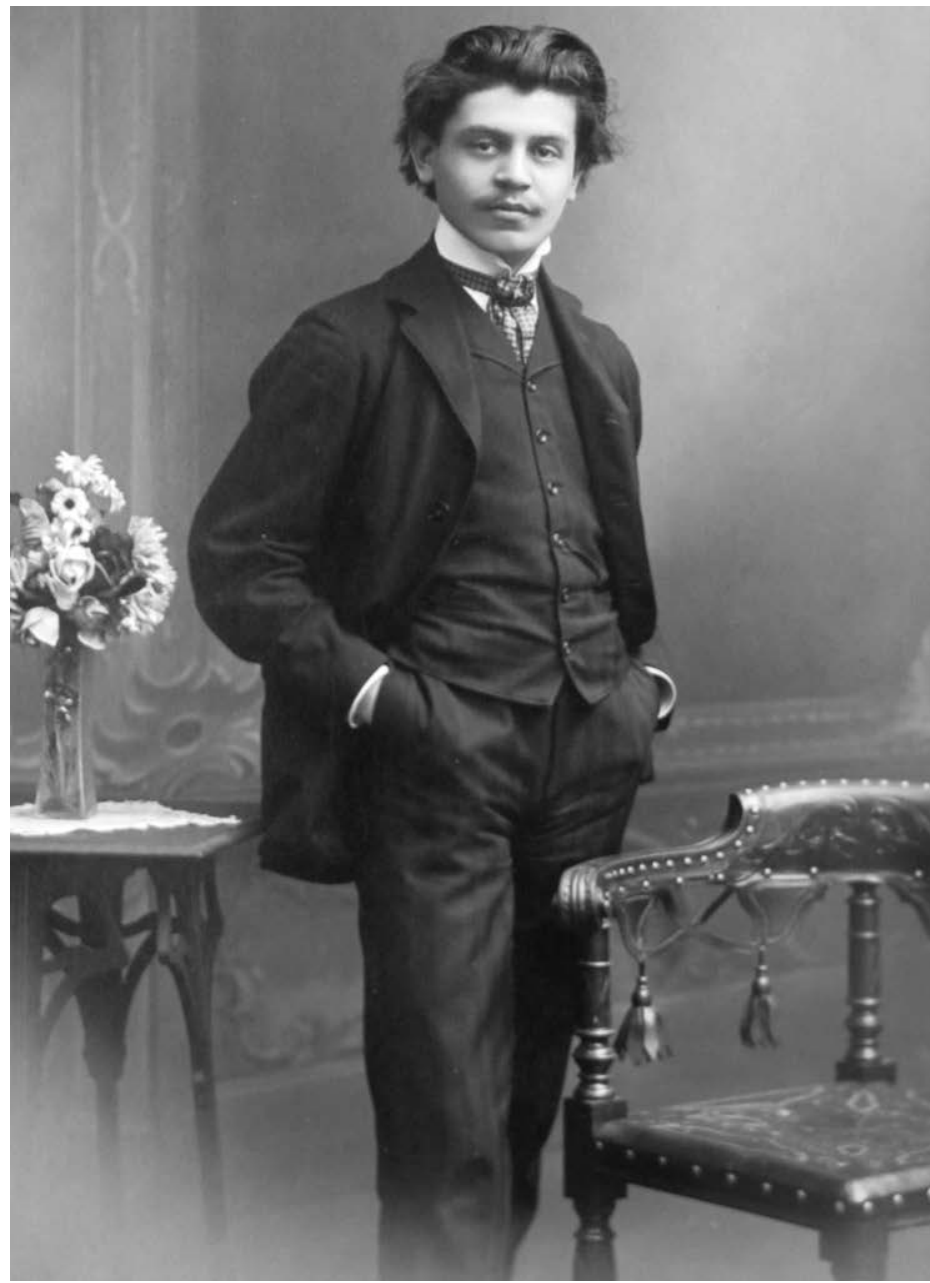

Obr. 3. Vilém Petrželka cca v roce 1912. Uloženo v ODH MZM, sine sign. 
